Article

\title{
Saccharoquinoline, a Cytotoxic Alkaloidal Meroterpenoid from Marine-Derived Bacterium Saccharomonospora sp.
}

\author{
Tu Cam Le ${ }^{1,+}{ }^{,}$Eun Ju Lee ${ }^{2,+}$, Jihye Lee ${ }^{1,3,+}$, Ahreum Hong ${ }^{4}$, Chae-Yoon Yim ${ }^{1}{ }^{(0)}$, Inho Yang ${ }^{5}$, \\ Hyukjae Choi ${ }^{6}{ }^{(}$, Jungwook Chin ${ }^{2}{ }^{-}$, Sung Jin Cho ${ }^{2}{ }^{-0}$, Jaeyoung $\mathrm{Ko}^{7}$, Hayoung Hwang ${ }^{2, *}$, \\ Sang-Jip Nam ${ }^{1, *}$ and William Fenical ${ }^{8, *}$ \\ 1 Department of Chemistry and Nano Science, Ewha Womans University, Seoul 03760, Korea; \\ lecamtu5789@gmail.com (T.C.L.); j13414@gmail.com (J.L.); yimgenie@gmail.com (C.-Y.Y.) \\ 2 New Drug Development Center, Daegu-Gyeongbuk Medical Innovation Foundation (DGMIF), Daegu 41061, \\ Korea; dmswn2588@naver.com (E.J.L.); jwchin@dgmif.re.kr (J.C.); sjcho@dgmif.re.kr (S.J.C.) \\ 3 Laboratories of Marine New Drugs, REDONE Seoul, Seoul 08594, Korea \\ 4 Graduate School of Industrial Pharmaceutical Sciences, Ewha Womans University, Seoul 03760, Korea; \\ lyzenne@naver.com \\ 5 Department of Convergence Study on the Ocean Science and Technology, Korea Maritime and Ocean \\ University, Busan 49112, Korea; ihyang@kmou.ac.kr \\ 6 College of Pharmacy, Yeungnam University, Gyeongsan, Gyeongsangbukdo 38541, Korea; h5choi@yu.ac.kr \\ 7 Basic Research \& Innovation Division Amorepacific R\&D Unit, Yongin 17074, Korea; \\ jaeyoungko@amorepacific.com \\ 8 Center for Marine Biotechnology and Biomedicine, Scripps Institution of Oceanography, University of \\ California-San Diego, La Jolla, CA 92093-0204, USA \\ * Correspondence: hwanghy@dgmif.re.kr (H.H.); sjnam@ewha.ac.kr (S.-J.N.); wfenical@ucsd.edu (W.F.) \\ + These authors contributed equally to this work.
}

Received: 31 December 2018; Accepted: 29 January 2019; Published: 2 February 2019

\begin{abstract}
A cytotoxic alkaloidal meroterpenoid, saccharoquinoline (1), has been isolated from the fermentation broth of the marine-derived bacterium Saccharomonospora sp. CNQ-490. The planar structure of 1 was elucidated by 1D, 2D NMR, and MS spectroscopic data analyzes, while the relative configuration of 1 was defined through the interpretation of NOE spectroscopic data. Saccharoquinoline (1) is composed of a drimane-type sesquiterpene unit in combination with an apparent 6,7,8-trihydroxyquinoline-2-carboxylic acid. This combination of biosynthetic pathways was observed for the first time in natural microbial products. Saccharoquinoline (1) was found to have cytotoxicity against the HCT-116 cancer cell line by inducing G1 arrest, which leads to cell growth inhibition.
\end{abstract}

Keywords: Saccharomonospora sp.; meroterpenoid; marine natural product; cytotoxicity

\section{Introduction}

The marine-derived bacterium Saccharomonospora sp. CNQ-490 is an actinomycete which, based upon phylogenetic analysis, represents a new operational taxonomic unit within the genus Saccharomonospora [1]. Previous chemical investigations of the strain CNQ-490 led to the isolation of a series of alkaloids, namely, the lodopyridones [1,2], which revealed a unique combination of ethanolamine, thiomethyl-substituted 4-pyridone, thiazole, and chloroquinoline moieties within its structure. A further study of this strain also yielded three new $\alpha$-pyrones-the saccharomonopyrones A-C [3]. Further, a recent genomic study on Saccharomonospora sp. CNQ-490 led to the successful heterologous expression of a silent bio-synthetic gene cluster, which lead to the discovery of the new 
anti-biotic taromycins A and B [4,5]. The observation of 19 apparent biosynthetic gene clusters in this strain also indicated that this actinomycete could be a promising source for additional structurally diverse secondary metabolites [4]. LC-MS analysis on a large-scaled culture crude extract of this strain revealed a peak with UV absorption signals at $\lambda_{\max } 281$ and $349 \mathrm{~nm}$, which corresponds to a molecular weight of 425 . HPLC-UV-guided purification of the culture extract of the strain yielded an alkaloidal meroterpenoid saccharoquinoline (1, Figure 1).

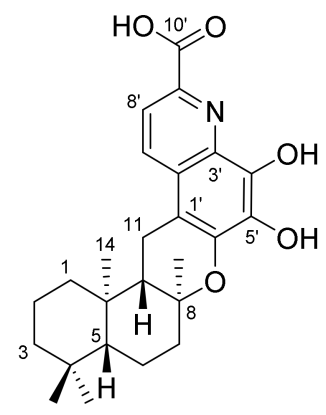

1

Figure 1. Chemical structure of saccharoquinoline (1).

\section{Results and Discussion}

\subsection{Chemical Structure Elucidation}

Saccharoquinoline (1) was isolated as a viscous oil by repeated $C_{18}$ silica flash column fractionation and final $\mathrm{C}_{18}$ HPLC purifications. The molecular formula of $\mathbf{1}$ was deduced as $\mathrm{C}_{25} \mathrm{H}_{31} \mathrm{NO}_{5}$ from the analysis of HRESIMS data in combination with NMR spectroscopic data. A strong IR absorption at $1708 \mathrm{~cm}^{-1}$ indicated the presence of carbonyl functionality, which was ultimately assigned as a carboxylic acid. The ${ }^{1} \mathrm{H}-\mathrm{NMR}$ spectrum of $\mathbf{1}$ exhibited two doublet ortho-aromatic protons $\left(\mathrm{H}-7^{\prime}\left(\delta_{\mathrm{H}}\right.\right.$ $8.40,1 \mathrm{H}, J=8.6 \mathrm{~Hz})$ and $\left.\mathrm{H}-8^{\prime}\left(\delta_{\mathrm{H}} 7.92,1 \mathrm{H}, J=8.6 \mathrm{~Hz}\right)\right)$, and four methyl singlets $\left(\mathrm{H}-12\left(\delta_{\mathrm{H}} 0.85\right)\right.$, $\mathrm{H}-13\left(\delta_{\mathrm{H}} 0.90\right), \mathrm{H}-14\left(\delta_{\mathrm{H}} 0.94\right)$, and $\left.\mathrm{H}-15\left(\delta_{\mathrm{H}} 1.18\right)\right)$. The ${ }^{13} \mathrm{C}$ NMR and HSQC spectroscopic data also indicated the presence of four methyl singlets $\left(C-12\left(\delta_{C} 21.5\right), C-13\left(\delta_{C} 33.2\right), C-14\left(\delta_{C} 14.6\right)\right.$, and C-15 $\left.\left(\delta_{C} 20.3\right)\right)$, six methylenes $\left(C-1\left(\delta_{C} 38.5\right), C-2\left(\delta_{C} 18.0\right), C-3\left(\delta_{C} 41.3\right), C-6\left(\delta_{C} 19.3\right), C-7\left(\delta_{C} 40.3\right)\right.$, and C-11 $\left.\left(\delta_{C} 17.9\right)\right)$, two methines $\left(C-5\left(\delta_{C} 55.3\right)\right.$ and $\left.C-9\left(\delta_{C} 51.2\right)\right)$, two aromatic methines $\left(C-7^{\prime}\left(\delta_{C} 132.1\right)\right.$ and $\left.C-8^{\prime}\left(\delta_{C} 116.9\right)\right)$, three un-protonated sp ${ }^{3}\left(C-4\left(\delta_{C} 32.8\right), C-8\left(\delta_{C} 78.1\right)\right.$, and $\left.C-10\left(\delta_{C} 36.6\right)\right)$, and eight un-protonated $\mathrm{sp}^{2}$ carbons $\left(\mathrm{C}-1^{\prime}\left(\delta_{\mathrm{C}} 104.9\right), \mathrm{C}-2^{\prime}\left(\delta_{\mathrm{C}} 122.8\right), \mathrm{C}-3^{\prime}\left(\delta_{\mathrm{C}} 133.6\right), \mathrm{C}-4^{\prime}\left(\delta_{\mathrm{C}} 135.0\right), \mathrm{C}-5^{\prime}\left(\delta_{\mathrm{C}}\right.\right.$ $136.9), C-6^{\prime}\left(\delta_{C} 145.8\right), C-9^{\prime}\left(\delta_{C} 140.8\right)$, and $\left.C-10^{\prime}\left(\delta_{C} 165.6\right)\right)$ (Table 1$)$.

Further interpretation of the $2 \mathrm{D}$ spectroscopic data allowed us to assign the structure of 1 . First, the drimane-type sesquiterpene unit was secured from the analysis of the COSY and HMBC spectroscopic data. COSY correlations $\left(\mathrm{H}-1\left(\delta_{\mathrm{H}} 0.99,1.83\right) / \mathrm{H}-2\left(\delta_{\mathrm{H}} 1.44,1.66\right) / \mathrm{H}-3\left(\delta_{\mathrm{H}} 1.18,1.39\right), \mathrm{H}-5\left(\delta_{\mathrm{H}} 1.08\right) / \mathrm{H}-6\right.$ $\left(\delta_{\mathrm{H}} 1.42,1.74\right) / \mathrm{H}-7\left(\delta_{\mathrm{H}} 1.73,2.15\right)$, and $\left.\mathrm{H}-9\left(\delta_{\mathrm{H}} 1.67\right) / \mathrm{H}-11\left(\delta_{\mathrm{H}} 2.69,2.91\right)\right)$, the HMBC correlations from gem dimethyls $\mathrm{H}_{3}-12$ and $\mathrm{H}_{3}-13$ to $\mathrm{C}-3, \mathrm{C}-4$, and $\mathrm{C}-5$, a methyl singlet $\mathrm{H}_{3}-14$ to $\mathrm{C}-1, \mathrm{C}-5, \mathrm{C}-9$, and $\mathrm{C}-10$, and from a methyl singlet $\mathrm{H}_{3}-15$ to $\mathrm{C}-7, \mathrm{C}-8$, and $\mathrm{C}-9$ permitted the establishment of a drimane moiety.

Second, the quinoline moiety could also be constructed by the interpretation of the 1D and 2D NMR spectroscopic data. The COSY spectrum confirmed two ortho-coupled aromatic protons, H-7' and $\mathrm{H}-8^{\prime}$. HMBC correlations were observed from $\mathrm{H}-8^{\prime}$ to $\mathrm{C}-2^{\prime}$, and from $\mathrm{H}-7^{\prime}$ to $\mathrm{C}-1^{\prime}, \mathrm{C}-3^{\prime}$, and $\mathrm{C}-9^{\prime}$, and from the exchangeable proton $4^{\prime}-\mathrm{OH}$ to $C-3^{\prime}, C-4^{\prime}$, and $C-5^{\prime}$. These observations, coupled with the presence of an aromatic nitrogen, suggested the presence of a quinoline moiety. The typical carbon chemical shifts of $C-5^{\prime}\left(\delta_{C} 136.9\right)$ and $C-6^{\prime}\left(\delta_{C} 145.8\right)$ indicated the attachment of oxygen atoms to $C-5^{\prime}$ and C- $6^{\prime}$. HMBC NMR correlations from methylene $\mathrm{H}_{2}-11$ to $\mathrm{C}-\mathrm{1}^{\prime}$ and $\mathrm{C}-6^{\prime}$ permitted the connectivity of $C-9 / C-11 / C-1^{\prime}$ and the typical oxygenated carbon chemical shift of $C-8\left(\delta_{C} 78.1\right)$ indicated the connectivity of C-8 and C-6 through an oxygen atom. Even though no relevant HMBC correlations 
were observed for the carboxylic group of C-10', this moiety was placed at C-9', which was based on the observation of ortho-coupled protons for protons $\mathrm{H}-\mathrm{7}^{\prime}$ and $\mathrm{H}-\mathrm{-}^{\prime}$. Quinoline-2-carboxylic acids are common metabolites and their spectroscopic data are well known. Thus, the planar structure of saccharoquinoline (1) was determined, as shown in Figure 2A.

The complete relative stereo-structure of $\mathbf{1}$ was readily derived by the interpretation of NOESY NMR correlations of the drimane skeleton. NOESY correlations between $\mathrm{H}-9$ and $\mathrm{H}-11 \beta\left(\delta_{\mathrm{H}} 2.69\right)$, and $\mathrm{H}-5$ and $\mathrm{H}-9$ indicated that those protons $(\mathrm{H}-5, \mathrm{H}-9$, and $\mathrm{H}-11 \beta)$ were located on the same side of the tricyclic ring system (Figure 2B).

Table 1. NMR spectroscopic data for saccharoquinoline (1) in DMSO- $d_{6}, \delta$ in ppm ${ }^{\mathrm{a}}$.

\begin{tabular}{|c|c|c|c|c|}
\hline \multirow{2}{*}{ No. } & \multicolumn{4}{|c|}{1} \\
\hline & $\delta_{\mathrm{C}}$, mult. $^{\mathrm{b}}$ & $\delta_{\mathrm{H}}(J$ in $\mathrm{Hz})$ & COSY & НMBC \\
\hline 1 & $38.5, \mathrm{CH}_{2}$ & $\begin{array}{c}0.99, \text { brd; } 1.83, \mathrm{~d} \\
(14.3)\end{array}$ & 2 & \\
\hline 2 & 18.0, $\mathrm{CH}_{2}$ & $1.44, \mathrm{~m}^{\mathrm{c}} ; 1.66, \mathrm{~m}^{\mathrm{c}}$ & 1,3 & \\
\hline 3 & $41.3, \mathrm{CH}_{2}$ & $1.18^{\mathrm{c}} ; 1.39^{\mathrm{c}}$ & 2 & \\
\hline 4 & $32.8, \mathrm{C}$ & & & \\
\hline 5 & $55.3, \mathrm{CH}$ & $1.08^{\mathrm{c}}$ & & $4,6,10,12,14$ \\
\hline 6 & $19.3, \mathrm{CH}_{2}$ & $1.42, \mathrm{~m}^{\mathrm{c}} ; 1.74, \mathrm{~m}^{\mathrm{c}}$ & 7 & \\
\hline 7 & $40.3, \mathrm{CH}_{2}$ & $\begin{array}{c}1.73^{\mathrm{c}} ; 2.15, \mathrm{dt}(12.3, \\
3.6)\end{array}$ & 6 & \\
\hline 8 & 78.1, C & & & \\
\hline 9 & $51.2, \mathrm{CH}$ & $1.67^{\mathrm{c}}$ & 11 & $8,10,11,14,15$ \\
\hline 10 & $36.6, \mathrm{C}$ & & & \\
\hline 11 & $17.9, \mathrm{CH}_{2}$ & $\begin{array}{l}2.69 \text {, dd }(16.8,5.2) \\
2.91 \text {, dd }(16.8,13.1)\end{array}$ & 9 & $8,9,1^{\prime}, 6^{\prime}$ \\
\hline 12 & $21.5, \mathrm{CH}_{3}$ & $0.85, \mathrm{~s}$ & & $3,4,5,13$ \\
\hline 13 & $33.2, \mathrm{CH}_{3}$ & $0.90, \mathrm{~s}$ & & $3,4,5,12$ \\
\hline 14 & $14.6, \mathrm{CH}_{3}$ & $0.94, \mathrm{~s}$ & & $1,5,9,10$ \\
\hline 15 & $20.3, \mathrm{CH}_{3}$ & $1.18, \mathrm{~s}$ & & $7,8,9$ \\
\hline $1^{\prime}$ & $104.9, \mathrm{C}$ & & & \\
\hline $2^{\prime}$ & $122.8, \mathrm{C}$ & & & \\
\hline $3^{\prime}$ & $133.6, \mathrm{C}$ & & & \\
\hline $4^{\prime}$ & 135.0, C & & & \\
\hline $5^{\prime}$ & 136.9, C & & & \\
\hline $6^{\prime}$ & $145.8, \mathrm{C}$ & & & \\
\hline $7^{\prime}$ & $132.1, \mathrm{CH}$ & $8.40, \mathrm{~d}(8.6)$ & $8^{\prime}$ & $1^{\prime}, 3^{\prime}, 9^{\prime}$ \\
\hline $8^{\prime}$ & $116.9, \mathrm{CH}$ & $7.92, \mathrm{~d}(8.6)$ & $7^{\prime}$ & $2^{\prime}$ \\
\hline $9^{\prime}$ & $140.8, \mathrm{C}$ & & & \\
\hline $10^{\prime}$ & 165.6, C & & & \\
\hline $4^{\prime}-\mathrm{OH}$ & & $9.54, \mathrm{~s}$ & & $3^{\prime}, 4^{\prime}, 5^{\prime}$ \\
\hline
\end{tabular}

$300 \mathrm{MHz}$ for ${ }^{1} \mathrm{H}$ NMR and $75 \mathrm{MHz}$ for ${ }^{13} \mathrm{C}$ NMR. ${ }^{\mathrm{b}}$ Numbers of attached protons were determined by analysis of 2D NMR spectroscopic data $(500 \mathrm{MHz}) .{ }^{\mathrm{c}}$ Overlapping signals.

Saccharoquinoline (1) is an alkaloidal meroterpenoid composed of a common drimane sesquiterpene and an unreported 6,7,8-trihydroxyquinoline-2-carboxylic acid moiety. Searches of the Antimarin Database showed 237 secondary metabolites containing the quinoline moiety isolated from microorganisms, but there were no reports of compounds having a hybrid structure, as in $\mathbf{1}$. The closest chemical structure to $\mathbf{1}$ is that of thallusin (2), which was isolated from the marine bacterium Flavobacterium sp. in 2005 [6]. Thallusin (2) has a broken ring structure between the C- $4^{\prime}$ and C- $5^{\prime}$ of 1, with a further oxidation state that has two carboxylic acids. The initial isolation of the thallusin was followed by several synthetic efforts [7,8]. In 2014, a chiral synthetic route based on enzymatic hydrolysis was developed to correct the originally proposed stereo-structure [9].

The structural similarity of these two meroterpenoids implies that they share the same biosynthetic pathway; however, they have an additional oxidative cleavage of the $\mathrm{C}-4^{\prime}-\mathrm{C}-5^{\prime}$ bond. 
It is not clear how these two metabolites are related. On the basis of feasible chemical conversions, the vicinal aromatic diol of $\mathbf{1}$ can be oxidized to the ring open dicarboxylic acid, in a fashion that is analogous to the oxidation of catechol to muconic acid [10]. Saccharoquinoline (1) and thallusin (2) show rare quinoline starting at the terpenoid pathway (Figure 3). A quinoline moiety from lodopyridones, which was isolated from the same strain, also supports this hypothesis $[1,2]$.

A)

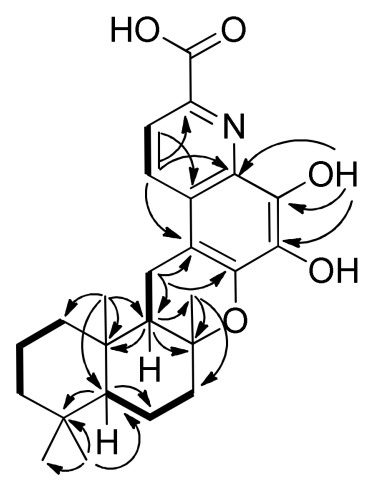

$\rightarrow$ COSY
B)

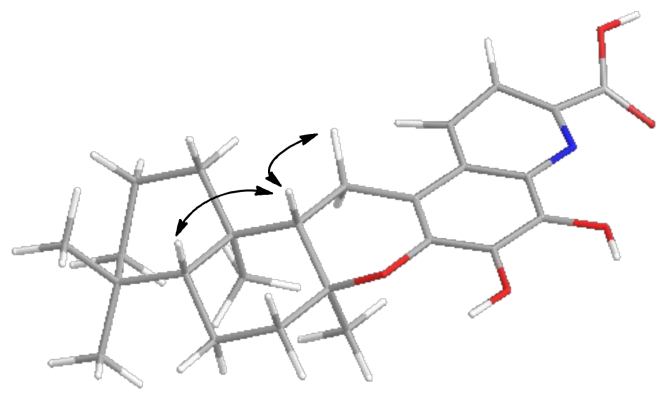

Figure 2. (A) COSY and key HMBC correlations. (B) Key NOESY correlations of saccharoquinoloine (1).<smiles>CC#CCCCCCCCCO</smiles>

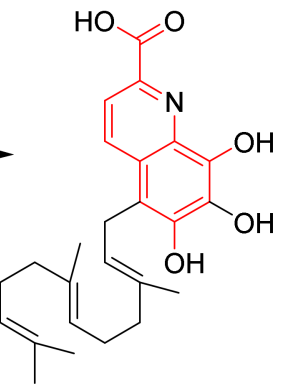

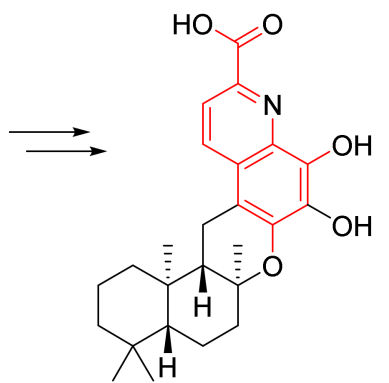

saccharoquinoline (1)

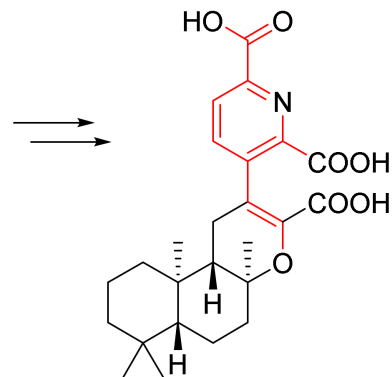

thallusin (2)

Figure 3. Plausible biosynthetic pathway for saccharoquinoline (1) and thallusin (2).

\subsection{Bioactivities}

Next, we tested saccharoquinoline (1) for its cytotoxic effect in diverse tumor-originating cancer cell lines such as H1299, A549, HCT116, PC-3, HepG2, and in the BJ normal cell line [11]. At a concentration of $10 \mu \mathrm{M}, 1$ induced cell growth inhibition of approximately 50\% in H1299 and HCT116. The treatment at the highest concentration of $25 \mu \mathrm{M}$ showed strong inhibition in the H1299, HCT116, and PC-3 cell lines, but also induced cell mortality of approximately $43 \%$ in the BJ cells (Table 2). Among the tested cancer cell lines, we chose the HCT116 colon cancer cells, which showed a high cytotoxic response, and confirmed the growth inhibition of $\mathbf{1}$ by using live cell growth measurements. As shown in Figure 4, 1 inhibited HCT-116 in a dose-dependent manner. Cell cycle regulation, and particularly G1 arrest, is one of the origins of cytotoxicity. Therefore, we compared the expressions of G1 check proteins such as CDKs and cyclins in the 1-treated and control cells. Figure 5 depicts the strong inhibition of cyclins D1 and D3, which play an important role in the transition from the G1 phase to the S phase. These data showed that saccharoquinoline (1) induced G1 arrest by the downregulation of cyclins D1 and D3 in colon cancer cells, resulting in cell growth inhibition [12]. 
Table 2. Viability assay in several types of cancer cells and normal cells after treatment with saccharoquinoline (1) for $72 \mathrm{~h}$.

\begin{tabular}{|c|c|c|c|c|c|c|c|}
\hline & \multirow{3}{*}{$\begin{array}{c}\text { Concentration } \\
(\mu \mathrm{M})\end{array}$} & \multicolumn{5}{|c|}{ Cancer } & \multirow{3}{*}{$\begin{array}{c}\text { Normal } \\
\text { Skin } \\
\text { BJ }\end{array}$} \\
\hline & & \multicolumn{2}{|c|}{ Lung } & \multirow{2}{*}{$\begin{array}{c}\text { Colon } \\
\text { HCT116 }\end{array}$} & \multirow{2}{*}{$\begin{array}{c}\text { Prostate } \\
\text { PC-3 }\end{array}$} & \multirow{2}{*}{$\begin{array}{c}\text { Liver } \\
\text { HepG2 }\end{array}$} & \\
\hline & & H1299 & A549 & & & & \\
\hline DMSO (0.1\%) & & 100 & 100 & 100 & 100 & 100 & 100 \\
\hline \multirow[t]{2}{*}{ Doxorubicin } & 10 & 6 & 5 & 11 & 24 & 7 & 16 \\
\hline & 1 & 87 & 103 & 89 & 106 & 98 & 87 \\
\hline \multirow[t]{2}{*}{1} & 10 & 45 & 100 & 39 & 88 & 82 & 80 \\
\hline & 25 & 29 & 81 & 25 & 46 & 71 & 57 \\
\hline
\end{tabular}

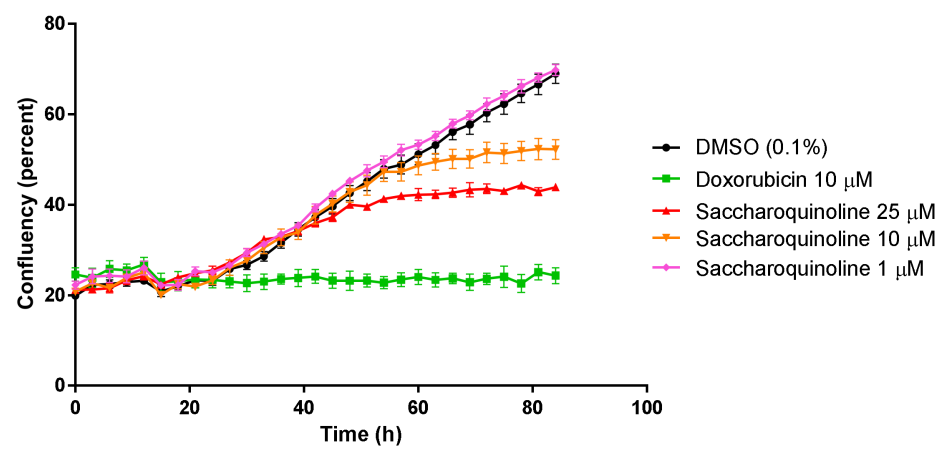

Figure 4. Colon cancer cell (HCT116) growth in saccharoquinoline (1)-treated and vehicle-treated (DMSO, 0.1\%) cells measured using live cell imaging. Doxorubicin treated cells were used as a control for cytotoxicity.

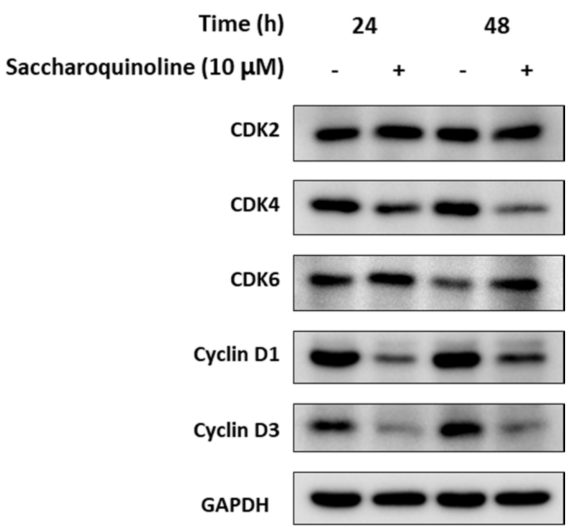

Figure 5. Downregulation of cell cycle checkpoint proteins involved in the G1 phase transition to the S phase. HCT116 cells were treated with $1(10 \mu \mathrm{M},+)$ for 24 hours or 48 hours, and with vehicle (DMSO, $0.1 \%)$. The expressions of CDK2, CDK4, CDK6, cyclin D1, and cyclin D3 were illustrated by Western blot analysis. GAPDH was used as the internal control.

\section{Materials and Methods}

\subsection{General Experimental Procedures}

An optical rotation was measured on an Autopol III (Rudolph Research Analytical, Hackettstown, NJ, USA) polarimeter with a 5-cm cell, and the UV spectra were recorded on a Scinco UVS-2100 spectrophotometer (Sinco, Daejeon, Korea). IR spectra were taken on a Perkin-Elmer 1600 FT-IR spectrometer (Waltham, MA, USA). NMR spectra were recorded on a Varian Inova NMR spectrometer (Varian Inc., Palo Alto, CA, USA; 300 and $75 \mathrm{MHz}$ for ${ }^{1} \mathrm{H}$ and ${ }^{13} \mathrm{C} \mathrm{NMR}$, respectively) using the signals of the residual solvent as internal references; $\delta_{\mathrm{H}} 2.50$ and $\delta_{\mathrm{C}} 39.5$ ppm for dimethyl sulfoxide- $d_{6}$ 
(DMSO- $d_{6}$ ). 2D NMR spectra were recorded on a Varian Inova $500 \mathrm{MHz}$ NMR spectrometer (Varian Inc., Palo Alto, CA, USA). High-resolution ESIMS spectra were obtained using a JEOL JMS-AX505WA mass spectrometer (JEOL Ltd. Tokyo, Japan). Low-resolution LC-MS data were acquired using an Agilent Technologies 6120 quadrupole LC/MS system (Agilent Technologies, Santa Clara, CA, USA) with a reversed-phase column (Phenomenex Luna C18 (2) $100 \AA$, $50 \mathrm{~mm} \times 4.6 \mathrm{~mm}, 5 \mu \mathrm{m}$ ) at a flow rate of $1.0 \mathrm{~mL} / \mathrm{min}$. Open column chromatography was performed on $\mathrm{C}_{18}$ silica $(40-63 \mu \mathrm{m}$, ZEO prep 90) with a gradient solvent of water $\left(\mathrm{H}_{2} \mathrm{O}\right)$ and methanol $(\mathrm{MeOH})$.

\subsection{Strain Isolation and Fermentation}

Strain CNQ-490 was isolated from a sediment sample collected at a depth of $45 \mathrm{~m}, 2 \mathrm{~km}$ west of the Scripps pier in La Jolla, CA. The $16 \mathrm{~S}$ rDNA sequence of this strain showed the closest identification with the genus Saccharomonospora (GenBank accession number EU214929). A 40-L culture of the strain CNQ-490 was performed at RT using 2.5-L Ultra Yield Flasks (Thomson Scientific, Oceanside, CA, USA), each containing $1 \mathrm{~L}$ of the medium $(10 \mathrm{~g} / \mathrm{L}$ of soluble starch, $2 \mathrm{~g} / \mathrm{L}$ of yeast, $4 \mathrm{~g} / \mathrm{L}$ of peptone, $10 \mathrm{~g} / \mathrm{L}$ of $\mathrm{CaCO} 3,20 \mathrm{~g} / \mathrm{L}$ of $\mathrm{KBr}, 8 \mathrm{~g} / \mathrm{L}$ of $\mathrm{Fe}_{2}\left(\mathrm{SO}_{4}\right)_{3} \cdot 4 \mathrm{H}_{2} \mathrm{O}$ dissolved in $1000 \mathrm{~mL}$ of artificial seawater) at $25{ }^{\circ} \mathrm{C}$ with shaking at $150 \mathrm{rpm}$. After 7 days of culture, the whole culture broth was extracted with ethyl acetate (EtOAc), and the solvent was removed in vacuo to yield $2.2 \mathrm{~g}$ of EtOAc extract.

\subsection{Extraction and Purification}

The organic extract was first fractionated by reversed-phase $\mathrm{C}_{18}$ silica flash chromatography using step-gradient elution $\left(80 \%\right.$ of $\mathrm{H}_{2} \mathrm{O}$ in $\mathrm{MeOH}$ to $100 \% \mathrm{MeOH}$, and $500 \mathrm{~mL}$ each, but the last solvent, which was $1000 \mathrm{~mL}$, had two fractions) to yield 10 fractions. Fraction 7, eluted with $80 \%$ of $\mathrm{MeOH}$ in water, contained saccharoquinoline (1). This fraction $(112 \mathrm{mg})$ was purified by reversed-phase HPLC under isocratic conditions with $60 \%$ of acetonitrile in $\mathrm{H}_{2} \mathrm{O}$ to yield $2.5 \mathrm{mg}$ of $\mathbf{1}$ (monitored with a UV detector at $281 \mathrm{~nm}$ and a retention time of 43.5 minutes).

Saccharoquinoline (1): Yellowish oil, $[\alpha]_{\mathrm{D}}^{25}+55$ (c 0.002, MeOH); UV (MeOH) $\lambda_{\max }(\log \varepsilon) 200$ (2.15), 281 (2.09), and 349 (1.24) nm; IR (KBr) $v_{\max } 3422,2927,1708,1624$, and $1452 \mathrm{~cm}^{-1} ;{ }^{1} \mathrm{H}$ and ${ }^{13} \mathrm{C}$ NMR data, Table 1 and Supplementary Materials; HRESIMS $m / z 426.2289[\mathrm{M}+\mathrm{H}]^{+}$(calcd for $\left.\mathrm{C}_{25} \mathrm{H}_{32} \mathrm{NO}_{5}, 426.2275\right)$.

\subsection{Cytotoxicity Test}

Cancer cell lines, obtained from ATCC (VA, USA), were cultured in a basal culture media containing 10\% FBS (GE Healthcare Life Sciences, Pittsburgh, PA, USA) and 1\% penicillin/streptomycin (GE Healthcare Life Sciences, Pittsburgh, PA, USA). The basal culture media used was MaCoys' 5A (Life Technologies, Carlsbad, MA, USA) for HCT116 (ATCC CCL-247), RPMI (Life Technologies, Carlsbad, MA, USA) for H1299 (ATCC CRL-5803), and DMEM (Life Technologies, Carlsbad, MA, USA) for A549 (ATCC CCL-185), PC-3 (ATCC CRL-1435), and HepG2 (ATCC HB-8065). The normal human fibroblast cell line, BJ (ATCC CRL-2522), was cultured in DMEM supplemented with $10 \%$ FBS and $1 \%$ penicillin/streptomycin. For the cytotoxicity test, cells with a total of $2.5 \times 10^{3}$ per well of the 96 well culture plate were seeded, and on the next day, saccharoquinoline (1) was treated as 1 , 10 , and $25 \mu \mathrm{M}$ in a basal media containing $1 \%$ FBS with a final concentration of $0.1 \%$ DMSO. Three days (72 h) after treatment, $100 \mu \mathrm{L}$ Cell Titer Glo reagent (Promega, Madison, WI, USA) was added to each well and luminescence activity was measured using a multifunctional microplate reader (Tecan, Männedorf, Switzerland). Cell viability was analyzed as percent (\%) viability compared with the DMSO (0.1\%)-treated control. Doxorubicin was used as a positive control. For HCT116 cell growth analysis in the live state, cells were seeded to be the number of $2.5 \times 10^{3}$ in each well of a 96-well plate, and cell growth, with or without treatment of $\mathbf{1}$, was monitored for 4 days. Cell growth was measured by the percent (\%) of cell confluence in each well of a 96-well plate using the IncuCyte ZOOM program (Sartorius, Göttingen, Germany). 


\subsection{Western Blot}

Saccharoquinoline $(1,10 \mu \mathrm{M}$, with $0.1 \%$ DMSO) or vehicle (DMSO, $0.1 \%$ ) was added to HCT116 cells cultured in a basal culture media supplemented with $1 \%$ FBS. Cells were harvested $24 \mathrm{~h}$ and $48 \mathrm{~h}$ after treatment and were lysed with RIPA (radioimmunoprecipitation assay) buffer (Roche, Basel, Switzerland) containing protease and phosphatase inhibitors (Roche). Cell lysates were kept on ice for $30 \mathrm{~min}$ and centrifuged at 15,000 rpm for $20 \mathrm{~min}$. Then, supernatants were transferred into new tubes and the protein concentrations were measured using a BCA protein assay kit (Thermo Fisher Scientific, Waltham, MA, USA). Next, the protein extracts (30 $\mu \mathrm{g})$ were electrophoresed and transferred to a PVDF membrane (EMD Millipore, Burlington, MA, USA). Then, the membrane was incubated with primary antibodies against CDK2, CDK4, CDK6, cyclin D1, cyclin D3, and GAPDH, purchased from Cell Signaling Technology (Danvers, MA, USA), at $4{ }^{\circ} \mathrm{C}$ overnight. The primary antibodies were detected by incubation with a horseradish peroxidase-conjugated secondary antibody (Bethyl Laboratories, Montgomery, TX, USA) at $25^{\circ} \mathrm{C}$ for $1 \mathrm{~h}$. Bindings of antibodies were visualized by an ImageQuant LAS4000 imager (GE Healthcare Life Sciences) after incubation with an ECL substrate (Bio-Rad, Hercules, CA, USA).

\section{Conclusions}

In conclusion, a cytotoxic alkaloidal meroterpenoid, saccharoquinoline (1), was isolated from Saccharomonospora sp. CNQ-490 as the first candidate for a hybrid structure between a drimane sesquiterpene and the rare 6,7,8-trihydroxyquinoline-2-carboxylic acid. The successful discovery of 1 along with the diversity of previously reported secondary metabolites from this Saccharomonospora strain, coupled with the genomic biosynthetic gene cluster information from previous studies, emphasizes the significant biosynthetic potential of the strain.

Supplementary Materials: The following are available online at http:/ /www.mdpi.com/1660-3397/17/2/98/s1, Figure S1: ${ }^{1} \mathrm{H}$ NMR spectrum $(300 \mathrm{MHz})$ of saccharoquinoline $(\mathbf{1})$ in DMSO- $d_{6}$; Figure S2: ${ }^{13} \mathrm{C}$ NMR spectrum (75 MHz) of saccharoquinoline (1) in DMSO- $d_{6}$; Figure S3: gCOSY spectrum $(500 \mathrm{MHz})$ of saccharoquinoline (1) in DMSO- $d_{6}$; Figure S4: gHSQC spectrum $(500 \mathrm{MHz})$ of saccharoquinoline (1) in DMSO- $d_{6}$; Figure S5: gHMBC spectrum $(500 \mathrm{MHz})$ saccharoquinoline (1) in DMSO- $d_{6}$; Figure S6: gNOESY spectrum $(500 \mathrm{MHz})$ of saccharoquinoline (1) in DMSO- $d_{6}$.

Author Contributions: T.C.L. and J.L. isolated the compound and elucidated the chemical structure. E.J.L., J.C., and S.J.C. performed bioassays. A.H. and C.-Y.Y. performed the large culture and extraction. I.Y., H.C., and J.K. contributed the NMR analysis and surveyed the literature, and contributed to writing the manuscript. H.H. was the project leader for the bioassay and analysis. S.-J.N. was the project leader for guiding the experiments of chemical analysis. W.F. was the project leader for chemical analysis, contributed the microbial strain and contributed to writing the manuscript.

Funding: The present study was supported by Basic Science Research Program through the National Research Foundation of Korea (NRF) funded by the Ministry of Science, ICT, and Future Planning under grant NRF-2017R1D1A1B03028172 (to S.-J.N.), and by the US National Cancer Institute (NIH) under grant R37 CA044848 (to W.F.).

Acknowledgments: We would like to thank Ji Sun Hwang from DGMIF for revising the manuscript.

Conflicts of Interest: The authors declare no conflict of interest.

\section{References}

1. Maloney, K.N.; MacMillan, J.B.; Kauffman, C.A.; Jensen, P.R.; Dipasquale, A.G.; Rheingold, A.L.; Fenical, W. Lodopyridone, a structurally unprecedented alkaloid from a marine Actinomycete. Org. Lett. 2009, 11, 5422-5424. [CrossRef] [PubMed]

2. Le, T.C.; Yim, C.-Y.; Park, S.; Katila, N.; Yang, I.; Song, M.C.; Yoon, Y.J.; Choi, D.-Y.; Choi, H.; Nam, S.-J.; et al. Lodopyridones B and C from a marine sediment-derived bacterium Saccharomonospora sp. Bioorgan. Med. Chem. Lett. 2017, 27, 3123-3126. [CrossRef] [PubMed] 
3. Yim, C.-Y.; Le, T.C.; Lee, T.G.; Yang, I.; Choi, H.; Lee, J.; Kang, K.-Y.; Lee, J.S.; Lim, K.M.; Yee, S.-T.; et al. Saccharomonopyrones A-C, new $\alpha$-pyrones from a marine sediment-derived bacterium Saccharomonospora sp. CNQ-490. Mar. Drugs 2017, 15, 239. [CrossRef] [PubMed]

4. Yamanaka, K.; Reynolds, K.A.; Kersten, R.D.; Ryan, K.S.; Gonzalez, D.J.; Nizet, V.; Dorrestein, P.C.; Moore, B.S. Direct cloning and refactoring of a silent lipopeptide biosynthetic gene cluster yields the antibiotic taromycin A. Proc. Natl. Acad. Sci. USA 2014, 111, 1957-1962. [CrossRef] [PubMed]

5. Reynolds, K.A.; Luhavaya, H.; Li, J.; Dahesh, S.; Nizet, V.; Yamanaka, K.; Moore, B.S. Isolation and structure elucidation of lipopeptide antibiotic taromycin B from the activated taromycin biosynthetic gene cluster. J. Antibiot. 2018, 71, 333-338. [CrossRef] [PubMed]

6. Matsuo, Y.; Imagawa, H.; Nishizawa, M.; Shizuri, Y. Isolation of an algal morphogenesis inducer from a marine bacterium. Science 2005, 307, 1598. [CrossRef] [PubMed]

7. Gao, X.; Matsuo, Y.; Snider, B.B. Synthesis of ent-thallusin. Org. Lett. 2006, 8, 2123-2126. [CrossRef] [PubMed]

8. Nishizawa, M.; Iyenaga, T.; Kurisaki, T.; Yamamoto, H.; Sharfuddin, M.; Namba, K.; Imagawa, H.; Shizuri, Y.; Matsuo, Y. Total synthesis and morphogenesis-inducing activity of $( \pm)$-thallusin and its analogues. Tetrahedron Lett. 2007, 48, 4229-4233. [CrossRef]

9. Yamamoto, H.; Takagi, Y.; Oshiro, T.; Mitsuyama, T.; Sasaki, I.; Yamasaki, N.; Yamada, A.; Kenmoku, H.; Matsuo, Y.; Kasai, Y.; et al. Total synthesis of (-)-thallusin: Utilization of enzymatic hydrolysis resolution. J. Org. Chem. 2014, 79, 8850-8855. [CrossRef] [PubMed]

10. Weber, C.; Brückner, C.; Weinreb, S.; Lehr, C.; Essl, C.; Boles, E. Biosynthesis of cis,cis-muconic acid and its aromatic precursors, catechol and protocatechuic acid, from renewable feedstocks by Saccharomyces cerevisiae. Appl. Environ. Microbiol. 2012, 78, 8421-8430. [CrossRef] [PubMed]

11. Mei, C.H.; Zhou, S.C.; Zhu, L.; Ming, J.X.; Zeng, F.D.; Xu, R. Antitumor effects of laminaria extract fucoxanthin on lung cancer. Mar. Drugs 2017, 15, 39. [CrossRef] [PubMed]

12. Han, M.; Cheng, X.; Gao, Z.; Zhao, R.; Zhang, S. Inhibition of tumor cell growth by adenine is mediated by apoptosis induction and cell cycle S phase arrest. Oncotarget 2017, 8, 94286-94296. [CrossRef] [PubMed]

(C) 2019 by the authors. Licensee MDPI, Basel, Switzerland. This article is an open access article distributed under the terms and conditions of the Creative Commons Attribution (CC BY) license (http:/ / creativecommons.org/licenses/by/4.0/). 